\title{
Supply Chain Integration as a Predictor of SSCM Practices on Operational Performance
}

\author{
Kwame Asamoah \\ Putra Business School, Universiti Putra Malaysia, Serdang, Selangor Darul Ehsan, Malaysia
}

Dr Hilla Limann Technical University, Box 553, Wa, Upper West, Ghana

\begin{abstract}
Devika Nadarajah
Putra Business School, Universiti Putra Malaysia, Serdang, Selangor Darul Ehsan, Malaysia
\end{abstract}

Received: August 1, $2021 \quad$ Accepted: October 16, $2021 \quad$ Published: October 17, 2021

doi:10.5296/bms.v12i2.18875 URL: https://doi.org/10.5296/bms.v12i2.18875

\begin{abstract}
There is no denying the fact that operations of manufacturing organisations have had adverse impact on the global environment and Ghana is no exception. Factors such as climate change, depletion of natural resources, environmental pollution and increase in carbon footprint as well as violation of human rights which have characterized the activities of these organisations over decades have led to a growing call by key stakeholders on manufacturing companies to have a paradigm shift in their approach to manufacturing in ways that meet environmental, economic, and social needs. It appears that an integration of manufacturing activities among channel members within the supply chain is a good approach in reducing the harmful effects of their operations, create value and wealth out of such activities and improve upon their operational performance. This paper is purposed to extend and strengthen theory building on sustainable supply chain management (SSCM) concept and supply chain integration to foster improved operational performance based on resource dependence theory.
\end{abstract}

Keywords: supply chain integration, SSCM, operational performance

\section{Background}

The sustainability literature is inundated with empirical findings that posit, among others, that the link between sustainable supply chain management practices (environmental, social and economic) and operational performance is by no means linear (Kang et al., 2018, Ahmed et al., 2018)). As a result, future researchers have been urged to help identify, through a diligent 
review of literature, plausible variables capable of accentuating the predictive power of the dimensions of sustainability on operational performance metrics. However, researchers such as Veera et al. (2016) and Kneipp, (2019) have lamented over the limited consideration supply chain integration has received in respect of its potential to play a mediating role in the relationship between SSCM practices and operational performance in the sustainability literature. The identified gap in literature as espoused above provides a reasonable ground for this conceptual paper which seeks to propose a comprehensive model that integrates the TBL dimensions, Supply Chain Integration and Operational Performance.

Utilising resource dependence theory (RDT) as key under-pinner, the proposed model is intended to examine the direct and indirect effects of SSCM dimensions on Operational Performance through Supply Chain Integration within the context of sustainability.

The integrated framework is the result of a thorough review of the extant literature relating to the sustainability context which considers supply chain integration as a potential driver capable of accentuating the predictive power of environmental, social and economic initiatives on Operational Performance. The outcome of this study is the development of testable propositions which lend themselves to future empirical investigations.

\section{Originality/value}

The study utilises resource rependence theory to develop a robust and comprehensive model that considers three dimensions of sustainability. This presents far-reaching implications for researchers as well as industry practitioners. As far as the researchers are concerned, these concepts have scarcely been examined as a holistic integrated model. As a result, the examination of the mediating effects of supply chain integration in the SSCM-Operational Performance chain/link is regarded as a novelty in the sustainability literature which provides profound insight on the mediating role of Supply Chain Integration in the aforesaid relationship. Finally, the proposed theoretical framework, from the perspectives of the authors, serves as a roadmap for successful implementation of sustainability initiatives.

\section{Introduction}

There is a universal acknowledgement of the devastating impact of manufacturing operations on the environment and society and this reality has been recognised by researchers such as Abdullah et al. (2015) and Hussein et al. (2018). This unfortunate state of affairs has generated increased calls from governments, civil society groups, international NGO's etc. for the manufacturing industry to integrate sustainable supply chain management practices into their operations that meet environmental, economic, and social needs. In particular, the industry is enjoined to pay attention to issues such as climate change, the depletion of natural resources and environmental pollution, resource usage, waste treatment, air emissions, water pollution, employee welfare etc. in order to salvage the environment and ameliorate the ever increasing warming of the globe and improve the well-being of society. For example, United Nations Environmental Programme (UNEP, 2015) reports that the manufacturing industry is responsible for 20 per cent of the world's CO2 emissions; additionally, Carbon Disclosure 
Project (2011) also reports that more than $20 \%$ of global greenhouse gas emissions are made by 2,500 largest global companies and their supply chains are responsible for a major proportion of emissions resulting from corporate emissions. These chilling statistics serve as a constant reminder to the manufacturing industry to have a clear departure from practices that harm the environment and people and the solution to this is the adoption of sustainable supply chain practices defined as the management of material, information and capital flows as well as cooperation among companies along the supply chain while taking goals from all three dimensions of sustainable development, i.e., economic, environmental and social into account which is derived from customer and stakeholder requirement (Seuring and Muller, 2008).

Ghana has not escaped from the negative manufacturing practices which have had devastating consequences on its environment and people as well as the profitability of these organisations. For instance, United Nations Environmental Programme (UNEP) (2015) mentions in their report, among others, that the environmental challenges which confront the country have had their source from the manufacturing sector, contributing a great deal of greenhouse gas emissions and toxins. Partnership for Action on Green Economy (PAGE) (2015) cites in its report that even though Ghana's industrial sector represents a vital segment of the economy, available statistics point to the fact that the manufacturing sector contributes significantly to water pollution and $\mathrm{CO} 2$ emissions, which in turn poses serious threat to the environment and health of individuals. Again, the statistics reflect a situation where $\mathrm{CO} 2$ emissions from manufacturing and construction industries have also been on the ascendency over the years. For instance, between 2000 and 2011, CO2 emissions from the manufacturing and construction industries doubled approximately with growth rate of 9.8 percent (Page, 2015). It is sad to note that these negative consequences of manufacturing operations have occurred on the back of failed government efforts, policy-wise, to goad the manufacturing industry to incorporate green practices into their operations. On top of that, Gyasi-Mensah and Xuhua (2018), posit that, in the context of Ghana, very limited research has been conducted on green practices, specifically in the manufacturing sector. Additionally, the limited research also lacks scientific analysis and theoretical backing which renders their findings weak for conclusions.

Whilst researchers such as Hussein et al. (2018) as well as Dubey et al. (2017) opine that the incorporation of SSCM initiatives into manufacturing operations can produce an outcome that significantly improves environmental, social and economic challenges as well as operational performance of firms, other authors such as Das (2018), Chu et. al. (2017) as well as Yonghy et al. (2018) have vehemently questioned the unconditional direct effect of SSCM practices on the operational performance of firms. Therefore, empirical findings regarding the SSCM-Operational Performance link still remain inconclusive with series of mixed reports in the extant literature. The gravamen of the mixed reports is that a mere implementation of SSCM initiatives by organisations does not automatically translate into improvement in operational performance and that is suggestive of the likelihood of the existence of some intervening variables that can enhance the relationship for the desired impact to occur. 
As a result, scholars such as Das (2018) and Chu et al. (2017) have recommended further studies to be done to identify variables that can be introduced into the SSCM-Operational Performance link for a significant enhancement of the relationship. In spite of this, literature on this subject remains largely undeveloped. To contribute to the unfolding debate in literature regarding the improvement in SSCM-Operational Performance, this study proposes a sustainability-performance model that empirically examines the mediating role of supply chain integration to further enhance the aforementioned relationship. These inter-related constructs, as far as the authors are concerned, have not been comprehensively studied in a single integrated model to clarify the influence of SSCM practices on firm performance, particularly, in the manufacturing industry.

Taking inspiration from the above, this study seeks to extend and validate the work carried out by Das (2018) and Chu et al. (2017) by the introduction of a mediator (supply chain integration) and to fill a research gap in literature and further extend the contemporary work of eminent scholars, using resource dependence theory as an under-pinner.

\section{Literature Review}

This section presents an analysis of the relevant academic literature that addresses the gaps that exist in the current literature in relation to the subject under review and which explains the relationship between SSCM practices and Operational Performance whilst critically examining the role played by supply chain integration in mediating the link.

\subsection{Operational Performance}

Operational performance is defined as the combination of product development efficiency, process improvements, quality conformity, and short lead times (Kotabe et al., 2003, p. 294; Croom, 2018). Das (2018) on the other hand explains operational performance to mean the extent of improvement in organizational performance in relation to a reduction in cost and improvement in efficiency along the entire supply chain. For instance, reduction in cost of purchased materials or cost of production as well as decrease in the energy consumption or cost of energy consumption were suggested by Green Jr. et al. (2012), Zailani et al. (2012), Harms et al. (2013), Laosirihongthong et al. (2013), and Esfahbodi et al. (2016). Further improvement in logistics efficiency was utilized by Zhou et al. (2008) as well as Park and Lee (2015). Flynn et al. (2010) also define operational performance as the way that a company can quickly modify products to meet customer requirements, quickly launch new products onto the market, respond to changes in demand, improve delivery times, reduce production or transfer lead times or to improve the overall service provided to the final customer. However, Croom (2018) posits that few studies have examined the relationship between sustainability practices and non-financial performance such as operational performance (see also Walker et al., 2014; Zorzini et al., 2015).

Finally, Yu et al. (2018) hold the view that the delivery and quality of products which are dimensions of operational performance have become one of the ambitious components that will make organizations remain and win in the international merchandized setting when they 
undertake effective operational performance measures. In this connection, operational performance has been regarded by many researchers as vital facilitator to the general supply chain performance which is measured by quality, flexibility, cost and delivery time (Prajogo et al., 2018, Nawamir et al., 2013; Yu et al., 2018). Scholarship within the SCM makes a proposition to the effect that industrial practitioners must make conscious effort to improve the effectiveness of their operations such that the safety and quality of products can be guaranteed. The basis of the above argument hinges on the fact that even though delivery of quality products is considered an essential element of operational performance within the administration of supply chain, it has attracted less attention by researchers, academicians and professionals (Lofti et al. 2013).

\subsection{Environmental Management Practices}

Increased market pressures and introduction of rigid environmental management by governments world-wide have made environmental issues a matter of grave global concern to firms (Delmas and Toffel, 2008). According to Montabon et al. (2007), environmental management practices (EMP) are a series of skills and plans put in place by firms with the mind-set of tracking and managing the consequences of their activities on the eco-system.

These practices have the potential to significantly improve a firm's environmental performance through the reduction of the negative impact of the firm's operations on the environment (Tyteca, 1996; Ulubeyli, 2013; Famiyeh et al, 2018). Hence, any deliberate attempt by a firm to bring to the barest minimum the incidents of ecological disasters, pollutants, resource discount rates, and consumption of hazardous materials is a clear indication of positive results for the natural environment (Geyer and Jackson, 2004; Zhu and Sarkis, 2004).

According to Dubey et al. (2018), some practices identified in the literature that fall under the environmental dimension include green product design, green packaging, green distribution and warehousing and conservation of natural resources as well as eco-friendly processes, technologies, products, energy-efficient systems and conservation techniques. More importantly, Handfield (2002) has forcefully argued for the inclusion of product recalls due to environmental concerns since such incidents may have telling impact on the financial health of organisations.

According to Choi et al (2018), there seems to be a dilemma generated by the firm's commitment to greening initiatives and the cost associated with such investment since the firm's environmental friendliness hardly comes free while its payoffs are not clearly known. In order to solve this dilemma, researchers have made several attempt to examine the influence of environmental management practices on the firm's performance in order to determine whether greening initiatives are worthy of investment and management focus (Choi et al., 2018).

Finally, Choi et al (2018) posit that an extensive review of the sustainability literature points to a paucity of findings regarding which particular environmental management practices or 
strategies were more effective in improving the firm's performance than their alternative options and that the scanty findings express doubt that the firm's environmental management practices could improve its performance. More importantly, literature on the above subject woefully failed to examine how the collective environmental management efforts of multiple firms belonging to the same supply chain network impacted those firms' performances. Finally, Choi et al (2018) found in their study to the effect that certain categories of EMP such as Internal Environmental Management, Green Purchasing, Eco-design, Cooperation with customers as well as Reverse Logistics have positive impact on certain aspects of the firm's activities such as manufacturing and marketing performance and further suggested that future research must develop a new yardstick to objectively assess the firm performance in non-financial terms.

\subsection{Social Practices}

Croom et al. (2018) opine that Socially Sustainable Supply Chain practices encapsulate varying degrees of initiatives that are crucial for global chains such as health and safety, child slave labour, working conditions, human rights and community impact programmes (see also Walker et al., 2014). Marshall et al. (2015) make a distinction between "basic" and "advanced" socially sustainable supply chain practices in the sustainability literature. According to them, "basic" practices involve the health and safety of workers in the supply chain, such as health and safety monitoring or management systems whereas "advanced" practices redefine the supply chain through new products or processes that benefit multiple stakeholder groups, promote transparency of social sustainability information and include NGOs and communities in supply chain decision making.

The general observation in the sustainability literature is that there is acute lack of research pertaining to the social aspect of the TBL and as a result, academics and managers find it difficult to delineate them and have little knowledge of their impact as well as understanding as to what really drives them (Marshall et al., 2017; Croom et al., 2018). Again Croom et al (2018) maintain that there is a clear gap in research in respect of Socially Sustainable Supply Chain (SSSC) practices because the extant literature so far largely focuses on environmental supply chain practices and have ignored the form, drivers or impacts of SSSC initiatives (refer to Klassen and Vereecke, 2012; Huq et al., 2014; Zorzini et al., 2015).

Finally, Ahmed et al. (2019) posit that limited research exists that empirically examine the factors affecting social sustainability initiatives and that such limited studies are generally based on qualitative and anecdotal data. Further, they are also limited to the extent that they partially investigate factors that drive the implementation of local labor standards (Oka, 2010; Toffel et al., 2015), which is a subset of social sustainability. More importantly, Ahmed et al., (2019) opine that relatively little research has examined large-scale empirical data to identify the institutional factors that influence the adoption of social sustainability initiatives (Porteous et al., 2015; Toffel et al., 2015). In sum, Toffel et al., (2015) drive home the need for further research that seeks to investigate the social processes underlying the association between supplier-level institutional factors and adoption of social sustainability initiatives 


\subsection{Economic Practices}

Broadly speaking, economic practices include indicators of traditional operational performance, such as cost, quality, flexibility and delivery, as well as measures of market and financial performance such as profitability, sales growth, and market share (Yang, 2013). According to Das (2018), a closer look at the extant literature reveals that most researchers in the sustainability literature equate economic practices with operations practices and tend to repeat this often since, in their considered view, the connotation 'economic practices' or 'economic performance' appears to be too broad or macro in nature. According to Das (2018), such a terminology fits the situation where the performance or practices of different industrial sectors are being considered for instance on quarterly, half-yearly or annual basis and it is seldom used to denote the performance of a single firm on economic dimension.

Das (2018) explains economic or operations practices to involve introduction of operations management techniques for enhancing efficiency, improving quality, reducing inventory, and minimizing waste across the entire value chain. According to him, some of the economic practices ubiquitous in the sustainability literature include but not limited to TQM, six sigma, value engineering, JIT, lean production, inventory management etc. Whiles researchers such as (Flynn et al., 1994; Kaynak, 2003; Chen and Paulraj, 2004; Kannan and Tan, 2005) consider quality management to be a key aspect of economic practices which include the implementation of quality management system that facilitates the building of quality into the product, selection of suppliers based on quality rather than cost, implementation of TQM/Six sigma etc., other researchers such as (Ibusuki and Kaminski, 2007; Behncke et al., 2014) rather suggest value engineering as a critical aspect of the economic or operational practices which must be implemented by the focal firm in order to gain competitive advantage and reduce the cost of components.

In a similar vein, other researchers such as (Tan et al., 2002; Kannan and Tan, 2005; Yang et al., 2011) recommended for adoption by firms scientific inventory control technique and implementation of JIT in the supply chain in order to improve efficiency and reduce inventory. Finally, other practices pertaining to economic dimension mentioned in the literature for adoption by firms include waste minimization, lean production as well as the application of economies of scale in transportation ( Tan et al., 2002; Kannan and Tan, 2005; Yang et al., 2013; Sheu and Chen, 2014; Wu et al., 2015).

\subsection{Supply Chain Integration}

Veera et al. (2016) define SCI to mean the integration of the entire activities within an organisation with the activities of suppliers, customers as well as other supply chain members. Thus, SCI effectively connects a firm with its customers, suppliers and other channel members by merging their relationships, activities, functions, processes and locations (Naslund and Hulthen, 2012). 
Sacristán-Díaz and Garrido-Vega (2018) further reveal that integration is positively related to operational performance and firm performance, via its influence on productivity and customer service (e.g., Jin et al., 2013). According to them, internal and external integrations have close affinity and both are pre-requisites for improved results to be realized by the organization. While internal integration entails a manufacturer's departments and functions working as part of an integrated process, external integration implies that close, interactive links should be forged with customers and suppliers (Stank et al., 2001; Flynn et al., 2010; Allred et al., 2011).

Veera et al. (2016) again scrutinised the extant literature and identified numerous gaps some of which include the fact that a more comprehensive model that examines the connection between SCMPs, SCI and OP is still missing. Therefore, an evaluation of the issues regarding how SCMPs and performance is mediated by the SCI is still unfocused. More importantly, they discovered the real gaps in the extant literature to also include the lack of empirical evidence on the relationship between SCMPs, integration and performance as well as the lack of empirical diagnosis on how and which aspect of SCMPs is critical for SCI and for SCP. They noted, that the overarching concerns of managers within the supply chain spectrum are to find answers regarding which dimension of SCMPs are likely to be mediated by SCI and which can eventually improve performance.

It can be observed from the above, that the results by Veera et al. (2016) as well as Sacristan-Diaz and Garrido-Vega (2018) regarding the relationship between SCMPs, and the mediating role of SCI and firm performance are mixed and inconclusive and need to be addressed as perspectives from this study will afford managers of manufacturing organizations in Ghana better options to practically exploit the varying aspects of SCMPs for SCI and operational and competitive performance.

More importantly, contemporary researchers posit that the success and effectiveness of the triple bottom line initiatives are essentially underpinned by a firm's ability to fittingly integrate its supply chain. Pagell (2004, p. 460) for instance mentions that "the entire concept of SCM is really predicated on integration". This position is accentuated by Zailani (2005) who affirms that integration of supply chains is considered to be of strategic as well as operational importance. Wolf (2011) concludes by suggesting that applying the concept of integration to sustainability may help prospective researchers to better understand the practices which make supply chains more sustainable and to assess the impact of such activities on sustainability performance.

\subsection{Environmental Management Practices and Operational Performance}

A comprehensive review of the extant literature reveals that firms that effectively plan and implement efficient and meaningful environmental management programmes and policies in tandem with eco-design initiatives end up having enhanced environmental and operational performance (Geyer and Jackson, 2004). For instance, Famiyeh et al. (2018) carried out an empirical study in Ghana to evaluate the link between environmental management practices 
(EMP) and competitive operational performance in relation to cost reduction, quality enhancement, enhanced flexibility and effective delivery as well as entire environmental performance of firms and found a significant positive relationship between EMP and competitive operational performance. According to them, the results of the study show that EMP initiated by firms have a significant positive effect on cost, quality, delivery and flexibility performance of those firms.

That clearly is an indication that deliberate efforts by firms to invest in EMP would lead to a reduction in cost, enhanced quality, improved delivery, and flexibility which in turn will improve their overall environmental performance in terms of conformity with environmental standards, reduced air pollution, and minimal intake of toxic raw materials (Famiyeh et al., 2018).

Finally, Jabbour et al. (2013) found in his research that EMP practices have a positive influence on Operational Performance, however, the relationship tends to be weak. According to them, further studies must be conducted to thoroughly ascertain the relationship in a different context.

The finding is an indication that the relationship between EMP and OP must be strengthened within the studied companies in order to generate the requisite synergy between them and thereby create win-win conditions. In view of this, the hypothesis below is proposed:

\section{H1: Environmental management practices significantly influence operational performance}

\subsection{Social Practices and Operational Performance}

Mani et al. (2017) report that improvement in working conditions in organisations will benefit the buyer's operational performance by way of accident reduction, fewer disruptions, and reduction in product delivery time (Freire and Alacon, 2002; Yuan and Woodman, 2010, Mani, 2017). Pagell et al. (2010) indicate that better working conditions for employees is one sure way of improving product quality which is due to the employees' enhanced motivation. Overall, firms that embrace social sustainability in the supply chain stand a greater chance of enjoying production economies with its added advantage of reduced health and safety cost, better product quality, shorter lead times and enhanced reputation (Carter and Rogers, 2008).

Consistent with the above, Croom et al. (2018) carried out a study which sought to explore the knowledge on the effect of social sustainability orientation on operational performance and found that social sustainability supply chain practices address pressing social issues and provide operational benefits that positively impact on society. On the contrary, Marshall et al. (2017) assert that the impact of sustainable social supply chain practices (SSSC) on the operational performance of firms remains "ambiguous". In their perspective, the limited studies identified in the literature find performance benefits from sustainable social supply chain management practices difficult to operationalize (see also Hollos et al., 2012). In sharp contrast, other studies found a positive relationship between general sustainability practices and knowledge and information-sharing capabilities (Pedersen, 2009), better collaboration 
(Wu and Pagell, 2011), and resulted in "cooperative advantages" from incorporating local community concerns (Strand, 2009) which are considered critical ingredients of operations performance endeavors of organisations. In the view of Klassen and Vereecke, (2012), SSSC practices may have a relationship with operational performance, however, they consider the relationship to be indirect since it only leads to improvements in the later through a reduction in operational risk and enhanced reputation through public recognition of SSSC adoption (refer to Brammer and Pavelin, 2006). According to Sodhi (2015), it is quite upsetting that this topic has received little attention from researchers in the sustainability literature and urges future researchers to fully investigate the topic. Following from this, the hypothesis below is proposed:

\section{H2: Social practices positively influence operational performance}

\subsection{Economic Practices and Operational Performance}

Das (2018) attempted to investigate the adoption of SSCM practices amongst manufacturing and process-based organisations in India and measure its impact on firm performance encompassing all three dimensions of sustainability. The study revealed that the connection between economic practices and competitiveness of a firm is indirect and insignificant but positive when mediated by some variable and that economic practices, regarded as the key activity of any firm, does not yield improved operations performance and competitiveness as most previous findings indicate.

Literature is inundated with findings that suggest significant relationship between advanced operations management systems and mass operational and lean operational performance (Gonzalez-Bento and Gonz alez-Bento 2005). Again, whiles Kaynak (2003) found in his research that TQM practices have positive effects on firm performance, Kannan and Tan (2005) rather demonstrated that key elements of operational practices such as supply chain integration, supply chain coordination, strategic commitment to quality etc. have positive impact on operational performance of a firm. Further, Shah and Ward (2007) establish a positive link between lean management and operations performance whiles Yang et al. (2011) also found that lean manufacturing practices carried out by firms could engender improved market performance and can eventually impact positively on the financial performance of such firms.

Finally, several other scholars including Yang Chen-Lung et al. (2010) and Li et al. (2006) project in their various findings that the implementation of supply chain practices and continuous improvement efforts like JIT and TQM leads to the manufacturing competitiveness of a firm in terms of its cost, quality, and delivery and additionally confirm that SCM practices encompassing all relevant components have significant positive impact on operational performance of a firm. The above argument leads me to propose the hypothesis below:

\section{H3: Economic practices have positive influence on operational performance}


2.9 Environmental Management Practices, Supply Chain Integration and Operational Performance

Vachon and Klassen (2008) cite in their study that joint environmental initiatives with channel members (such as joint environmental goal setting, shared environmental planning and collective effort towards pollution reduction etc.) have a positive impact on manufacturing performance. This view expressed above is also accentuated by Huq et al. (2016) who posit that working together with suppliers along the supply chain can assist firms to identify and overcome varying sustainability difficulties to enhance their operational performance (see also Klassen and Vachon, 2003).

Additionally, Sacristán-Díaz and Garrido-Vega (2018) reveal that integration is positively related to operational performance and firm performance, via its influence on productivity and customer service (e.g., Jin et al., 2013). In spite of the above, Veera et al. (2016) opine that a more comprehensive framework that examines the complex association between Sustainable Supply Chain Management Practices, SCI and OP is still missing. More importantly, contemporary researchers posit that the success and effectiveness of the triple bottom line initiatives are essentially underpinned by a firm's ability to fittingly integrate its supply chain. Pagell (2004, p. 460) for instance mentions that "the entire concept of SCM is really predicated on integration".

Taking cue from the foregoing arguments and relying on RDT, the following hypothesis is drawn:

H7: SCI mediates the relationship between EMP and $O P$

\subsection{Social practices, SCI and Operational Performance}

For instance, Pagell and Gobeli (2009) report that employee well-being initiatives are positively associated with operational performance. In view of the steady growth recorded in respect of injuries recorded in the workplace for a decade and beyond, prioritising safety in the workplace has become a better alternative for securing employees' health, safety and welfare promotion (Dasetal., 2008; Okunetal., 2016) because it goes without saying that good health and safety conditions are critical to firms practising sustainability (refer to Jørgensen, 2008). Overall, focal firms have increasingly come to appreciate the strategic importance of sustainability as the basis to managing their major suppliers' performance (Kang et al., 2018). Kang et al. (2018) again argue that internal integration practices carried out by a firm such as improvement in employee well-being etc. tend to enhance the social dimension of sustainability with its attendant advantage of improving its operational performance (see also Pagell and Gobeli, 2009; Voorde et al., 2012). In addition to the above, Bai and Sarkis, (2010) opine that evaluation exercise that takes into account qualifications of suppliers affords focal organisations the opportunity to manage their reputations and corporate legitimacy. Furthermore, Kang et al. (2018) conclude that engaging in collaborative activities with suppliers within the supply chain can help a company identify the various difficulties that arise from sustainability issues, including those of an environmental and social nature. 
Gimenez and Tachizawa (2012) underscore the importance of collaborating with suppliers of reputable firms involved in child labour practices in order to compel them to comply with local and international regulations. According to them, a company that deals with such erring suppliers who fail to adhere to the tenets of TBL attract more risks and loses legitimacy in the eyes of society which can eventually affect its bottom line. Integration of the supply chain makes it possible for the focal firm to identify suppliers who engage in unfair labour practices and whose activities destroy the source of livelihood of the communities where they operate. Such suppliers can subsequently be blacklisted and given opportunity to right the wrongs before being re-engaged. This gives the focal organisations competitive advantage. Additionally, getting suppliers to improve the working conditions of their employees and offering them constant training and good working tools leads to improvement in quality of products, reduced lead times, low costs and superior performance (Smith and Barclay, 1997; Pujari, 2006; Ageron et al., 2012; Gimenez et al., 2012)

Based on the strength of the argument advanced by Kang et al. (2018) as well as Das (2018) and relying on resource dependence theory as the underpinning theory, the following hypothesis is proposed:

H8: Supply Chain Integration mediates the relationship between Social Practices and Operational Performance.

\subsection{Economic Practices, Supply Chain Integration and Operational Performance}

Zeng et al. (2016) posit that the use of appropriate evaluation schemes to measure and assess suppliers in relation to the extent of their adherence to sustainability standards shields companies from potential risks related to environmental damage and violations of social standards. Thus, monitoring may forestall unnecessary financial loss due to the high probability that supplier evaluations would improve environmental performance and bring about positive economic performance. Developing the long term capacity of suppliers to meet rigorous sustainability standards has been a smart solution to the rising level of supplier-related accidents in many countries. Firms that transfer knowledge through education and training programs relating to sustainability criteria are more likely to build mutual trust with their suppliers and enhance their economic, environmental and social as well as operational performance (Kang and Moon, 2016). Although committing resources towards the upgrading of suppliers' knowledge of sustainability standards may be costly and require a prolonged time frame for the invested funds to be recovered, such activities, in the long-run, bring sustainable power to a company, allowing it to deal with unexpected disruptions that may destroy its supply chain and negatively impact its finances (Das, 2018).

Carter (2005) suggests that collaborating with suppliers and getting them to incorporate into their businesses economic practices such as waste reduction goals and encouraging them to devote asset-specific investments to engage in the design for disassembly and reuse and developing capable minority business enterprise suppliers may be costly and time consuming, nonetheless, such endeavours can have a strong positive influence on supplier performance 
and reduced operating costs in supply chain relationships.

According to Wolf (2014), RDT posits that an organization's survival depends on its ability to procure critical resources from the external environment and the ability of the organisation to achieve this objective is predicated on proper integration of its supply chain (Pfeffer and Salancik 1978) which explains the dependence of one organization upon another in gaining access to valuable resources (Emerson 1962; Pfeffer and Salancik 1978). Ulrich and Barney (1984) argue that "Dependence" confers a degree of power to the organization controlling the resources required by another and that such a strategy would imply the development of advanced relational capabilities with suppliers of scarce and critical resources (Parmigiani et al. 2011; Reuter et al. 2010). Dwelling on RDT and based on the foregoing argument, the following hypothesis is proposed:

\section{H9: SCI mediates the relationship between Economic Practices and Operational Performance}

\subsection{Conceptual Framework}

The preceding discussion led to the formulation of the conceptual model as depicted in figure one (1). The framework exhibits direct and indirect relationships amongst SSCM practices (environmental, social and economic), operational performance and supply chain integration. The study draws from resource dependence theory to explain the transmission mechanisms by which SSCM practices predict operational performance based on the mediating effect of supply chain integration. The development of the model is predicated on the widely-held view in the sustainability literature that points to the fact that organisations stand the biggest chance of improving their operations performance, the environment and the society when they strategically incorporate sustainable business practices to meet environmental, social and economic needs. This is variously described as the win-win approach by researchers such as Saeed et al. (2018) and Hussein et al. (2018).

Resource Dependence Theory (RDT) is concerned with the resources available in the environment but external to the focal firm and in the custody of other companies (see also Salancik and Pfeffer, 2003; Hollos et al., 2012). Companies having custody of those resources try to continue their grip to maintain their authority and dominance while those companies in need of them try to find alternate resources or new sources to minimize their dependence (Sheu, 2014). The underlying rationale of the theory hinges on the fact that an increase in dependence on resources by organisations in a supply chain will compel them to lean towards vertical integration and that resource dependence is positively related to vertical coordination. More importantly, Ellram (1992) and Arminas (2004) contend that as firms become increasingly dependent on scarce and valued resources, they will be compelled to increase integration with other members within the supply chain so as to gain access to vital and imitable knowledge by forming supplier partnerships and strategic alliances with customers as well developing joint ventures, or even purchasing sources of supply in order to continue to be sustainable and improve its operational performance and this underscores the 
mediating role of supply chain integration.

Sustainable Supply Chain Management practices are considered exogenous constructs, Operational Performance as endogenous variable because it constitutes the outcome of the study whilst supply chain integration is considered as the mediating variable because of its capacity to predict the endogenous variable. This is shown in the conceptual framework below:

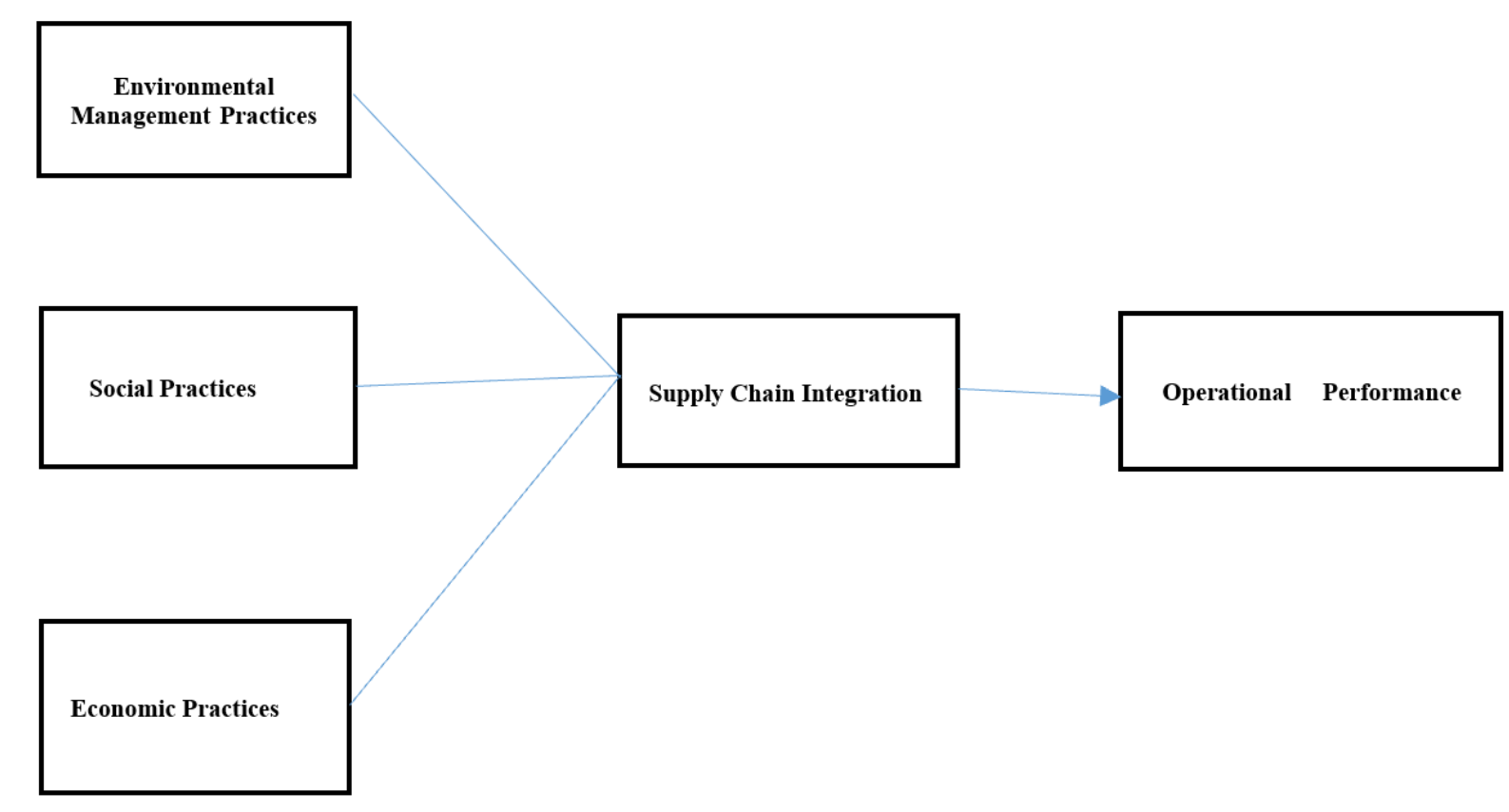

Figure 1. Proposed Conceptual Framework

Resource Dependence Theory

\subsection{Discussion}

Researchers such as Das (2018) and Dubey et al. (2017) have strongly argued, on the basis of empirical findings, that the link between sustainable supply chain management practice and operational performance is non-linear and will require some intervening variable to amplify the desired impact. In their view, this interesting finding warrants further investigation. This study draws inspiration from the finding and recommendation by the afore-mentioned authors by the introduction of supply chain integration to accentuate the power of the Triple Bottom Line to correctly predict operational performance. The authors develop a research proposition hinged on resource dependence theory that paves way for future research directions, including further development of the model's propositions. The conceptual model provides a bird's eye-view of the sustainability literature by way of the introduction of supply chain integration into the TBL-performance relationship with the view to broadening the fundamental conceptualisation of the construct sustainability, beyond the TBL to consider key supporting entities which are deemed to be pre-requisites to the implementation of SSCM practices especially within the context of a less developed country such as Ghana. Further, the consideration of the mediating effects of supply chain integration in the 
SSCM-Performance link is considered one of a kind in the sustainability scholarship which, on one hand, presents theoretical and practical implications for researchers and practitioners. On the other hand, the conceptual model is expected to yield findings that will guide future implementation of sustainability initiatives.

\subsection{Conclusion}

The researchers take the view that the interrelationships amongst SSCM practices, operational performance and resource dependence theory can only be validated through empirical testing. In connection with that, a study is currently ongoing to explain the aforementioned relationships with data drawn from some selected manufacturing organisations in Ghana. The empirical findings are expected to offer significant lessons to supply chain practitioners and useful directions for future research. The study, on the whole, is designed to resolve the apparent lack of theoretical justification in literature that explains the relationship amongst the three variables: sustainable supply chain management practices, supply chain integration and operational performance and to heighten the current level of awareness and the practical necessity associated with the adoption and implementation of sustainability initiatives especially among manufacturing firms.

\section{References}

Abdullah, N. A., \& Yaakub, S. (2015). The pressure for reverse logistics adoption among manufacturers in Malaysia. Asian Journal of Business and Accounting, 8(1), 152-177.

Ageron, B., Gunasekaran, A., \& Spalanzani, A. (2012). Sustainable supply management: an empirical study. International of Journal Production Economics, 140, 168-182. https://doi.org/10.1016/j.ijpe.2011.04.007

Ahmed, W., Ahmed, W., \& Najmi, A. (2018). "Developing and analyzing framework for understanding the effects of GSCM on green and economic performance: perspective of a developing country. Management of Environmental Quality: An International Journal, 29(4) 740-758. https://doi.org/10.1108/MEQ-11-2017-0140

Ahmed, W., Najmi, A., \& Khan, F. (2019). Examining the impact of institutional pressures and green supply chain management practices on firm performance. Management of Environmental Quality: An International Journal, 1477-7835. https://doi.org/10.1108/MEQ-06-2019-0115

Allred, B. B. (2012). Patent Rights: When Patent Protection May Either Encourage or Discourage Innovation. Interdisciplinary Approaches to Product Design, Innovation, \& Branding in International Marketing Advances in International Marketing, 23, 223-240. https://doi.org/10.1108/S1474-7979(2012)0000023015

Arminas, D. (2004). Steel yourself for price increases. Supply Management, 9(25), 14.

Bai, C., \& Sarkis, J. (2010). Green supplier development: Analytical evaluation using rough set theory. Journal of Cleaner Production, 18(12), 1200-1210. 
https://doi.org/10.1016/j.jclepro.2010.01.016

Behncke, F. G. H., Maisenbacher, S., \& Maurer, M. (2014). Extended Model for Value Engineering. Proced. Comput. Sci., 28, 781-788. https://doi.org/10.1016/j.procs.2014.03.093

Brammer, S. J., \& Pavelin, S. (2006). Corporate reputation and social performance: the importance of fit, Journal of Management Studies, 43 (3), 435-455. https://doi.org/10.1111/j.1467-6486.2006.00597.x

Carbon Disclosure Project (2011). Statistical report and investor guide-Project energy corporation: 2011Annual Report, 6-8, 14 and 25-27.

Carter, C. R., \& Rogers, D. S. (2008). A framework of sustainable supply chain management: moving toward new theory. Int. J. Phys. Distrib, Losgist. Manag., 38(5), 360-387. https://doi.org/10.1108/09600030810882816

Chen, I., \& Paulraj, A. (2004). Towards a theory of supply chain management: the constructs and measurements. Journal of Operations Management, 22(2), 119-150. https://doi.org/10.1016/j.jom.2003.12.007

Chen, L., Olhager, J., \& Tang, O. (2014). Manufacturing facility location and sustainability: a literature review and research agenda, International Journal of Production Economics, 149, 154-163. https://doi.org/10.1016/j.ijpe.2013.05.013

Choi, S. B., \& Min, Joo, H. Y. (2018). Examining the inter-relationship among competitive market environments, green supply chain practices, and firm performance. The International Journal of Logistics Management, 29(3), 1025-1048. https://doi.org/10.1108/IJLM-02-2017-0050

Choi, T. Y., \& Krause, D. R. (2006). The supply base and its complexity: Implications for transaction costs, risks, responsiveness, and innovation. Journal of Operations Management, 24(5), 637-652. https://doi.org/10.1016/j.jom.2005.07.002

Chu, H. S., Yang, H. L. M., \& Park, S. (2017). The Impact of Institutional Pressures on Green Supply Chain Management and Firm Performance: Top Management Roles and Social Capital. Sustainability, (9), 764. https://doi.org/10.3390/su9050764

Croom, S., Vidal, N., Spectic, W., Marshall, D. \& McCarthy, L. (2018). Impact of social sustainability orientation and supply chain practices on operational performance. International Journal of Operations \& Production Management, 38(12), 2344-2366. https://doi.org/10.1108/IJOPM-03-2017-0180

Das, D. (2018). The impact of Sustainable Supply Chain Management Practices on Firm Performanace: Lessons from Indian Organisations. Journal of Cleaner Productions, 203(2018), 179-196. https://doi.org/10.1016/j.jclepro.2018.08.250

Delmas, M. A., \& Toffel, M. W. (2008). Organizational responses to environmental demands: opening the black box. Strategic Management Journal, 29(10), 1027-1055. 
https://doi.org/10.1002/smj.701

Dubey, R., Altay, N., Gunasekaran, A., Blome, C., Papadopoulos, T., \& Childe, S. J. (2018).Supply chain agility, adaptability and alignment: empirical evidence from the Indian auto components industry", International Journal of Operations \& Production Management, 38(1), 129-148. https://doi.org/10.1108/IJOPM-04-2016-0173

Dubey, R., Gunasekaran, A., Childe, S. J., Papadopoulos, T., Hazen, B., Giannakis, M., \& Roubaud, D. (2017). Examining the effect of external pressures and organizational culture on shaping performance measurement systems (PMS) for sustainability benchmarking: Some empirical findings. Int. J. Prod. Econ. 193, 63-76. https://doi.org/10.1016/j.ijpe.2017.06.029

Ellram, L. M. (1992). Patterns in international logistics. Journal of Business Logistics, 13(1), 1-25.

Emerson, R. M. (1962). Power-dependence relations. American Sociological Review, 27(1), 31-41. https://doi.org/10.2307/2089716

Esfahbodi, A., Zhang, Y., \& Watson, G. (2016). Sustainable supply chain management in emerging economies: trade-offs between environmental and cost performance. Int. J. Prod. Econ., 181(Part B), 350-366. https://doi.org/10.1016/j.ijpe.2016.02.013

Fameyeh, S., Adaku, E., Amoako-Gyimpah, K., Asante-Darko, D., \& Amoatey, C. T. (2018). Environmental management practices, operational competitiveness and environmental performance: Empirical evidence from a developing country. Journal of Manufacturing Technology Management, 29(3), 588-607. https://doi.org/10.1108/JMTM-06-2017-0124

Flynn, B. B., Huo, B., \& Zhao, X. (2010). The impact of supply chain integration on performance: a contingency and configuration approach. J.Oper.Manage., 28, 58-71. https://doi.org/10.1016/j.jom.2009.06.001

Flynn, B. B., Schroeder, R. G., \& Sakakibara, S. (1994). A framework for quality management research and an associated measurement instrument. J. Oper. Manag., 11(4), 339-366. https://doi.org/10.1016/S0272-6963(97)90004-8

Freire, J., \& Alarcon, L. F. (2002). Achieving lean design process: improvement methodology. J. Constr. Eng. Manag., 128(3), 248-256.

https://doi.org/10.1061/(ASCE)0733-9364(2002)128:3(248)

Geyer, R., \& Jackson, T. (2004). Supply loops and their constraints: the industrial ecology of recycling and reuse. Calif. Manag. Rev., 46(2), 55-73. https://doi.org/10.2307/41166210

Gimenez, C., \& Tachizawa, E. M. (2012). Extending sustainability to suppliers: a systematic literature review. Supply Chain Management: An International Journal, 17(5), 531-543. https://doi.org/10.1108/13598541211258591

Gimenez, C., Sierra, V., \& Rodon, J. (2012). Sustainable operations: their impact on the triple bottom line. Int. J. Product. Econ. https://doi.org/10.1016/j.ijpe.2012.01.035 
González-Benito, J., \& González-Benito, Ó. (2005). Environmental proactivity and business performance: An empirical analysis. Omega, 33, 1-15. https://doi.org/10.1016/j.omega.2004.03.002

Green, K., Jr. Zelbst, P., Meacham, J., \& Bhadauria, V. (2012). Green supply chain management practices: impact on performance. Supply Chain Management: An International Journal, 17(3), 290-305. https://doi.org/10.1108/13598541211227126

Gyasi-Mensah, W., \& Xuhua H. (2018). Towards Developing a Green Manufacturing Environment: What is Ghana doing? Environmental Management and Sustainable Development, 7(2), 2164-7682. https://doi.org/10.5296/emsd.v7i2.12814

Handfield, R., Sroufe, R., \&Walton, S. (2005). Integrating environmental management and supply chain strategies. Bus. Strategy Environ., 14, 1-19. https://doi.org/10.1002/bse.422

Harms, D., Hansen, E. G., \& Schaltegger, S. (2013). Strategies in sustainable supply chain management: an empirical investigation of large German companies. Corp. Soc. Responsib. Environ. Manag., 20(4), 205-218. https://doi.org/10.1002/csr.1293

Hollos, D., Blome, C., \& Foerstl, K. (2012). Does sustainable supplier co-operation affect performance? Examining implications for the triple bottom line. Int. J. Prod. Res., 50, 2968-2986. https://doi.org/10.1080/00207543.2011.582184

Huq, F., Chowdhury, I., \& Klassen, R. (2016). Social management capabilities of multinational buying firms and their emerging market suppliers: an exploratory study of the clothing industry. Journal of Operations Management, 46, 19-37. https://doi.org/10.1016/j.jom.2016.07.005

Huq, F., Stevenson, M., \& Zorzini, M. (2014). Social sustainability in developing country suppliers. International Journal of Operations and Production Management, 34(5), 610-638. https://doi.org/10.1108/IJOPM-10-2012-0467

Hussein, H. (2018). A critique of water scarcity discourses in educational policy and textbooks in Jordan. The Journal of Environmental Education 49(3), 260-271. https://doi.org/10.1080/00958964.2017.1373620

Hutchins, M. J., \& Sutherland, J. W. (2008). An exploration of measures of social Sustainability and their application to supply chain decisions. Journal of Cleaner Production, 16(15), 1688-1698. https://doi.org/10.1016/j.jclepro.2008.06.001

Ibusuki, U., \& Kaminski, P. C. (2007). Product Development Process with Focus on Value Engineering and Target Costing: a case study in an automotive company. Int. J. Prod. Econ. 105(2), 459-474. https://doi.org/10.1016/j.ijpe.2005.08.009

Jabbour, C. J. C., Jugend, D., de Sousa Jabbour, A. B. L., Gunasekaran, A., \& Latan, H. (2015). Green product development and performance of Brazilian firms: measuring the role of human and technical aspects. Journal of Cleaner Production, 87, 442-451. 
https://doi.org/10.1016/j.jclepro.2014.09.036

Jin, X., \& Weber, K. (2015). Exhibition destination attractiveness - organizers' and visitors' perspectives. International Journal of Contemporary Hospitality Management, 28(12), 2795-2819. https://doi.org/10.1108/IJCHM-01-2015-0023

Jørgensen, T. B. (2006). Value Consciousness and Public Management. International Journal of Organization Theory and Behaviour, 9(4), 510-536. https://doi.org/10.1108/IJOTB-09-04-2006-B003

Kang, S., Kang, B., Shin, K., Kim, D., \& Han, J. (2018). A theoretical framework for strategy Kannan, V. R., \& Tan, K. C. (2005). Just in time, total quality management and supply chain management: understanding their linkages and impact on business performance. Omega 33(2), 153-162. https://doi.org/10.1016/j.omega.2004.03.012

Kaynak, H. (2003). The relationship between total quality management practices and their effects on firm performance. J. Oper. Manag. 21(4), 405-435. https://doi.org/10.1016/S0272-6963(03)00004-4

Klassen, R. D., \& Vereecke, A. (2012). Social issues in supply chains capabilities link responsibilities risk (opportunity) and performance. International Journal of Production Economics, 140(1), 103-115. https://doi.org/10.1016/j.ijpe.2012.01.021

Kneipp, J. M., Gomes, C. M., Bichueti, R. S., Frizzo, K., \& Perlin, A. P. (2019). Sustainable innovation practices and their relationship with the performance of industrial companies. Revista de Gestão, 26(2), 94-111. https://doi.org/10.1108/REGE-01-2018-0005

Kotabe, M., Martin, X., \& Domoto, H. (2003). Gaining from vertical partnerships: knowledge transfer, relationship duration, and supplier performance improvement in the US and Japanese automotive industries. Strategic Management Journal, 24(4), 293-316. https://doi.org/10.1002/smj.297

Laosirihongthong, T., Adebanjo, D., \& Tan, K. C. (2013). Green supply chain management practices and performance. Ind. Manag. Data Syst., 113(8), 1088-1109. https://doi.org/10.1108/IMDS-04-2013-0164

Li, S., \& Lin, B. (2006). Accessing information sharing and information quality in supply chain management", Decision Support Systems, 42(3), 1641-1656. https://doi.org/10.1016/j.dss.2006.02.011

Li, S., Ragu-Nathan, B., Ragu-Nathan, T. S., \& Rao, S. S. (2006). The impact of supply chain management practices on competitive advantage and organizational performance. Omega, 34(2), 107-124. https://doi.org/10.1016/j.omega.2004.08.002

Lotfi, Z., Sahran, S., Mukhtar, M., \& Zadeh, A. T. (2013). The relationships between supply chain integration and product quality. Procedia Technology, 11, 471-478. https://doi.org/10.1016/j.protcy.2013.12.217 
Mani, V., Delgado, C., Hazen, B. T., \& Patel, P. (2017). Mitigating supply chain risk via sustainability using big data analytics: evidence from the manufacturing supply chain", Sustainability, 9(4), 608. https://doi.org/10.3390/su9040608

Marshall, D., McCarthy, L., Claudy, M., \& McGrath, P. (2017). Piggy in the middle: how direct customer power affects first-tier suppliers' adoption of socially responsible procurement practices and performance. Journal of Business Ethics. https://doi.org/10.1007/s10551-016-3387-0

Marshall, D., McCarthy, L., Heavey, C., \& McGrath, P. (2015). Environmental and social supply chain management sustainability practices: Construct development and measurement. Prod. Plan. Control, 26, 673-690. https://doi.org/10.1080/09537287.2014.963726

Montabon, F., Sroufe, R., \& Narasimhan, R. (2007). An examination of corporate reporting, environmental management practices and firm performance. Journal of Operations Management, 25(5), 998-1014. https://doi.org/10.1016/j.jom.2006.10.003

Näslund, D., \& Hulthén, H. (2016). Framework for measuring performance of the sales and operations planning process. International Journal of Physical Distribution \& Logistics Management, 46(9), 809-835. https://doi.org/10.1108/IJPDLM-05-2016-0139

Nawanir, G., Lim, K. T., Norezam, O. S., \& Adeleke A. Q. (2018). Developing and validating lean manufacturing constructs: an SEM approach. Benchmarking: An International J., 1382-1405. https://doi.org/10.1108/BIJ-02-2017-0029

Oka, C. (2010). Accounting for the gaps in labour standard compliance: the role of reputation-conscious buyers in the Cambodian garment industry. The European Journal of Development Research, 22(1), 59-78. https://doi.org/10.1057/ejdr.2009.38

Okun, A. H., Guerin, R. J., \& Schulte, P. A. (2016). Foundational workplace safety and health competencies for the emerging workforce. Journal of Safety Research, 59, 43-51. https://doi.org/10.1016/j.jsr.2016.09.004

PAGE (2015). Ghana's Transition to a Green Economy: A Stocktaking Report

Pagell, M. (2004). Understanding the factors that enable and inhibit the integration of operations, purchasing and logistics. Journal of Operations Management, 22(5), 459-487. https://doi.org/10.1016/j.jom.2004.05.008

Pagell, M., \& Gobeli, D. (2009). How plant managers' experiences and attitudes toward sustainability relate to operational performance. Production and Operations Management, 18(3), 278-299. https://doi.org/10.1111/j.1937-5956.2009.01050.x

Pagell, M., \& Wu, Z. (2009). Building a more complete theory of sustainable supply chain management using case studies of 10 exemplars. J. Supply Chain Manage., 45(2), 37-56. https://doi.org/10.1111/j.1745-493X.2009.03162.x

Park, Y. R., Song, S., Choe, S., \& Baik, Y. (2015). Corporate social responsibility in 
international business: illustrations from Korean and Japanese electronics MNEs in Indonesia. J. Bus. Ethics 129 (3), 747-761. https://doi.org/10.1007/s10551-014-2212-x

Parmigiani, A., Klassen, R., D., \& Russo, M. V. (2011). Efficiency meets accountability:Performance implications of supply chain configuration, control, and capabilities. Journal of Operations Management, 29(3), 212-223. https://doi.org/10.1016/j.jom.2011.01.001

Pedersen, E. R. \& Andersen, M. (2006), Safeguarding corporate social responsibility (CSR) in global supply chains: how codes of conduct are managed in buyer-supplier relationships", Journal of Public Affairs, 6(3-4), 228-240. https://doi.org/10.1002/pa.232

Pfeffer, J., \& Salancik, G. R. (1978). The external control of organizations: A resource dependence perspective. Stanford: Stanford University Press.

Pfeffer, J., \& Salancik, G.R. (2003). The External Control of Organizations: A Resource Dependence Perspective; Stanford University Press: Palo Alto, CA, USA.

Porteous, A. H., Rammohan, S. V., \& Lee, H. L. (2015). Carrots or sticks? Improving social and environmental compliance at suppliers through incentives and penalties. Production and Operations Management, 24(9), 1402-1413. https://doi.org/10.1111/poms.12376

Prajogo, D. (2011). The roles of firms' motives in affecting the outcomes of ISO 9000 adoption. International Journal of Operations \& Production Management, 31(1), 78-100. https://doi.org/10.1108/01443571111098753

Pujari, D., Wright, G., \& Peattie, K. (2003). Green and competitive: influences on environmental new product development performance. Journal of Business Research, 56(8), 657-671. https://doi.org/10.1016/S0148-2963(01)00310-1

Reuter, C., Foerstl, K., Hartmann, E., \& Blome, C. (2010). Sustainable global supplier management: The role of dynamic capabilities in achieving competitive advantage. Journal of Supply Chain Management: A Global Review of Purchasing \& Supply, 46(2), 45-63. https://doi.org/10.1111/j.1745-493X.2010.03189.x

Sacristan-Diaz, M., Garrido-Vega, P., \& Moyano-Fuentes, J. (2018). Mediating and non-linear relationships among supply chain integration dimensions. International Journal of Physical Distribution \& Logistics Management: Emerald Publishing Limited, 48(7), 698-723. https://doi.org/10.1108/IJPDLM-06-2017-0213

Saeed, A., Jun, Y., Nubour, S. A., Priyankara, H. P. R., \& Jayasuriya, M. P. F. (2018). Institutional Pressures, Green Supply Chain Management Practices on Environmental and Economic Performance: A Two Theory View. Sustainability,10, 1517. https://doi.org/10.3390/su10051517

Sebastiani, R., Corsaro, D., Montagnini, F., \& Caruana, A. (2014). Corporate sustainability in action. Serv. Ind. J. 34(7), 584-603. https://doi.org/10.1080/02642069.2014.886191 
Seuring, S., \& Müller, M. (2008). From a literature review to a conceptual framework for sustainable supply chain management. J. Clean. Prod. 16(15), 1699-1710. https://doi.org/10.1016/j.jclepro.2008.04.020

Shah, R., \& Ward, P. T. (2007). Defining and developing measures of lean production. Journal of Operations Management, 25(1), 785-805. https://doi.org/10.1016/j.jom.2007.01.019

Sheu, J. B. (2014). Green supply chain collaboration for fashion able consumer electronics products under third-party power intervention-A resource dependence perspective. Sustainability, 6, 2832-2875. https://doi.org/10.3390/su6052832

Sheu, J. B., \& Chen, Y. (2014). Transportation and economies of scale in recycling low value materials. Transp. Res. Part B 65, 65-76. https://doi.org/10.1016/j.trb.2014.03.008

Smith, J. B., \& Barclay, D. W. (1997). The effects of organizational differences and trust on the effectiveness of selling partner relationships. The Journal of Marketing, 61(1), 3-21. https://doi.org/10.1177/002224299706100102

Sodhi, M. S. (2015). Conceptualizing social responsibility in operations via stakeholder resource-based view. Production and Operations Management, 24(9), 1375-138. https://doi.org/10.1111/poms.12393

Stank, T. P., Keller, S. B., \& Closs, D. J. (2001). Performance benefits of supply chain logistical integration", Transportation Journal, 41(2/3), 32-46.

Strand, R. (2009). Corporate responsibility in Scandinavian supply chains", Journal of Business Ethics, 85(1), 179-185. https://doi.org/10.1007/s10551-008-9937-3

Tan, K. C., Lynan, S. B., \& Wisner, J. D. (2002). Supply Chain Management: a Strategic perspective. Int. J. Oper. Prod. Manag. 22(6), 614-631. https://doi.org/10.1108/01443570210427659

Toffel, M. W., Short, J. L., \& Ouellet, M. (2015). Codes in context: how states, markets, and civil society shape adherence to global labor standards". Regulation \& Governance, 9(3), 205-223. https://doi.org/10.1111/rego.12076

Tyteca, D. (1996). On the measurement of the environmental performance of firms: a literature review and a productive efficiency perspective", Journal of Environmental Management, 46(3), 281-308. https://doi.org/10.1006/jema.1996.0022

Ulrich, D., \& Barney, J. B. (1984). "Perspectives in organizations: Resource dependence, efficiency, and population", Academy of Management Review, 9(3), 471- 481. https://doi.org/10.5465/amr.1984.4279680

Ulubeyli, S. (2013). Drivers of environmental performance of cement plants", Industrial $\begin{array}{llll}\text { Management } \quad \text { D } \quad \text { Data } & \text { Systems, } & 113(8), & 1222-1244 .\end{array}$ https://doi.org/10.1108/IMDS-01-2013-0007 
UNEP (2015) Green Economy Assessment Report”, Ghana

Vachon, S., \& Klassen, R. D. (2006). Extending green practices across the supply chain. Int. J. Opera. Prod. Manag, 26(7), 795-821. https://doi.org/10.1108/01443570610672248

Veera, P. K. S., Chandran, V. G. R., \& Bhatti, M. A. (2016). Supply chain practices and performance: the indirect effects of supply chain integration. Benchmarking: An International Journal, 23(6), 1445-1471. https://doi.org/10.1108/BIJ-03-2015-0023

Voorde, K. V. D., Paauwe, J., \& Veldhoven, M. V. (2012). Employee well-being and the HRM-organizational performance relationship: a review of quantitative studies. International $\begin{array}{llll}\text { Journal of } \quad \text { Management } & \text { Reviews, }\end{array}$ https://doi.org/10.1111/j.1468-2370.2011.00322.x

Walker, H., Seuring, S., Sarkis, J., \& Klassen, R. (2014). Sustainable operations management: recent trends and future directions. International Journal of Operations \& Production Management, 34(5), 1. https://doi.org/10.1108/IJOPM-12-2013-0557

Wolf, J. (2014).The relationship between sustainable supply chain management, stakeholder pressure and corporate sustainability performance. J. Bus. Ethics, 119, 317-328. https://doi.org/10.1007/s10551-012-1603-0

Wu, C., Fang, D., Liao, P., Xue, J., Li, Y., \& Wang, T. (2015). Perception of corporate social responsibility: the case of Chinese international contractors. J. Clean Production. 107(16), 185-194. https://doi.org/10.1016/j.jclepro.2015.04.143

Wu, Z., \& Pagell, M. (2011). Balancing Priorities: Decision-making in sustainable supply chain Management. Journal of Operations Managemnt. 29(6), 577-590. https://doi.org/10.1016/j.jom.2010.10.001

Yang, C. L., Lin, S. P., Chan, Y. H., \& Sheu, C. (2010). Mediated effect of environmental management on manufacturing competitiveness: an empirical study", International Journal of Production Economics, 123(1), 210-220. https://doi.org/10.1016/j.ijpe.2009.08.017

Yang, M. G. (2013). Developing a Focal Firm's Sustainability Chain Framework: ProQuest No.10631395, LLC-2017.

Yang, M. G., Hong, P., \& Modi, S.M. (2011). Impact of lean manufacturing and environmental management on business performance: an empirical study of manufacturing firms. Int. J. Prod. Econ. 129(2), 251-261. https://doi.org/10.1016/j.ijpe.2010.10.017

Yongyi, S. Li, Y., Park, Y., \& Kang, M. (2018). Supply chain integration and operational performance: The contingency effects of production systems. Journal of Purchasing and Supply Management, 24,(2018), 352-360. https://doi.org/10.1016/j.pursup.2017.11.004

Yu, C., Zhang, Z., Lin, C., \& Wu, Y. J. (2017). Knowledge creation process and sustainable competitive advantage: The role of technological innovation capabilities. Sustainability, 9, 2280. https://doi.org/10.3390/su9122280 
Yuan, F., \& Woodman, R. W. (2010). Innovative behavior in the workplace: the role of performance and image outcome expectations. Acad. Manag. J. 53 (2), 323-342. https://doi.org/10.5465/amj.2010.49388995

Zailani, S., \& Rajagopal, P. (2005). Supply chain integration and performance: US versus East Asian companies. Supply Chain Management: An International Journal, 10(5), 379-393. https://doi.org/10.1108/13598540510624205

Zailani, S., Jeyaraman, K., Vengadasan, G., \& Premkumar, R. (2012). Sustainable supply chain management (SSCM) in Malaysia: a survey. Int. J. Prod. Econ. 140(1), 330-340. https://doi.org/10.1016/j.ijpe.2012.02.008

Zeng, H., Chen, X., Xiao, X., \& Zhou, Z. (2016). Institutional pressures, sustainable supply chain management, and circular economy capability: Empirical evidence from Chinese eco-industrial park firms. Journal of Cleaner Production, 155 (2017), 54-65. https://doi.org/10.1016/j.jclepro.2016.10.093

Zhu, Q., \& Sarkis, J. (2004). Relationships between operational practices and performance among early adopters of green supply chain management practices in Chinese manufacturing enterprises. J. Oper. Manag. 22(3), 265-289. https://doi.org/10.1016/j.jom.2004.01.005

Zhu, Q., Sarkis, J., \& Lai, K. H. (2008). Confirmation of measurement model for green supply chain management practices implementation. Int. J. Prod. Econ. 111(2), 261-273. https://doi.org/10.1016/j.ijpe.2006.11.029

Zorzini, M., Hendry, L., Huq, F., \& Stevenson, M. (2015). Socially responsible sourcing: reviewing the literature and its use of theory", International Journal of Operations and Production Management, 35(1), 60-109. https://doi.org/10.1108/IJOPM-07-2013-0355

\section{Copyright}

Copyright for this article is retained by the author(s), with first publication rights granted to the journal.

This is an open-access article distributed under the terms and conditions of the Creative Commons Attribution license (http://creativecommons.org/licenses/by/4.0/). 